\title{
Communicating COVID-19 on Social Media: The Effects of the Spiral of Silence
}

\author{
Arthur Atanesyan \\ Professor and Applied Sociology Department Chair, Yerevan State University \\ Address: Alex Manoogian 1, Yerevan 0025, Armenia \\ E-mail: atanesyan@ysu.am \\ Anahit Hakobyan \\ Doctoral Student, Department of Applied Sociology, Yerevan State University \\ Address: Alex Manoogian 1, Yerevan 0025, Armenia \\ E-mail: anahit1989@gmail.com \\ Bradley Reynolds \\ Doctoral Student, University of Helsinki \\ Address: P.O. Box 4 (Yliopistonkatu 3), ooo14 University of Helsinki, Finland \\ E-mail: bradley.reynolds@helsinki.fi
}

\begin{abstract}
In this paper, the Spiral of Silence theory (SOS) in the study of mass communications is applied to examine the trends and mechanisms of public opinion in Social Media (SM), using the popular topic of the COVID-19 pandemic. The study includes a secondary analysis of the data on pandemic information consumption obtained through four mass surveys conducted in Armenia. In the period from July 1 to August 30, 2020, we also surveyed Armenian Facebook users by means of Google forms during the highest outbreak of the pandemic in Armenia. In particular, the study demonstrates that although the majority of people are well informed about both public conduct requirements and the sanctions for misconduct during the pandemic, they do not follow the rules but hide their real opinion, preferring to openly agree with the official position while silently breaking the rules (that is, they keep their silence). We have found a correlation between the opinion environment of "friends" and other Facebook users, and a willingness to express their own opinion. Due to the predominance of the self-presentation mode as a communication strategy on Facebook, there is a trend among Armenian users not to risk their reputation, and avoid possible critics by keeping silence, if the discussion goes against their opinion. The findings of the study might be helpful both for the further development of communication theories and its application to the conditions of new pandemic reality, and for a better understanding of communicative behavior mechanisms in SM.
\end{abstract}

Keywords: Spiral of Silence (SOS) theory, Social Media (SM), mass communications, behavior, COVID-19 pandemic, collectivist societies, Armenia, Facebook

\section{The Spiral of Silence Logic in Social Media}

Social media (SM) is defined as "Internet-based, disentrained, and persistent channels of mass personal communication facilitating perceptions of interactions among users, deriving value primarily from user-generated content" (Carr, Hayes, 2015). SM is developed on the platform of Internet social network sites (SNS), and tends to gradually replace traditional mass media (de Zúñiga et al., 2012). As a mass communication medium, SM has 
a number of characteristics, including: (1) a programmability as the capacity of a central agency to manipulate content in order to define the audience's watching experience as a continuous flow; (2) popularity (agenda-setting) as an ability to push certain topics to the fore, making it measurable and quantified; (3) connectivity as a function connecting the content, users activities, and advertisers, and (4) datafication as a function rendering many aspects of the world that have never before been quantified into data (van Dijck, Poell, 2013).

Due to its advantages over traditional media and constant technological innovation, SM not only reflects but also shapes and directs (redirects) public discourse, actively affecting social and political processes (Comninos, 2011). The information exchange through SM is quick, allowing to overcome any physical distance, bridging geographical, political, and economic periphery with the center, "flattening" public perceptions by increasing similarities and decreasing varieties (Friedman, 2006), and synchronizing the actions of communication participants (Metzger, Tucker, 2017; Zayani, 2016). Through the virtualization of communication between different population strata, economic differences of SM users get eliminated in favor of popular discourse (Breuer, 2012). The illusion of equality caused by virtual communication on SM makes it symbolically and functionally attractive to the audience. Thanks to virtual technologies, information from a mobile phone (for example, a video filmed by a witness of an accident) uploaded directly to SNS might serve as an alternative news channel, and then appear on TV. Thus, SM has the effect of multiplying information (Brouwer, Bartels, 2014). One of the key factors that affect the shaping of public opinion representation on SNS is the news consumption culture (Ohlsson et al., 2017).

In order to understand whether public opinion representation on SNS is affected by the same (similar) mechanisms as those used by traditional mass media, we apply the Spiral of Silence theory (SOS) as developed by Elizabeth Noelle-Neumann (Simpson, 1996). According to the SOS theory, the guiding mechanism preventing expressing one's opinion publicly is the fear of being isolated; if people consider their opinion to be dominant or likely to become such, they tend to express it publicly. If they decide that opinion is on the minority side or is likely to become such, they tend to show conformity and choose to remain silent (Liu, Fahmy, 2011). Led by the "fear of isolation", individuals are less likely to express their own viewpoint when they believe their opinions and ideas are in the minority. As a consequence, they tend to be misled about the real situation with public opinion. According to the SOS, a desire to avoid negative social sanctions tends to leave the person socially ostracized (Neuwirth et al., 2007).

The everyday monitoring of the so-called "public opinion climate" (Lee, Yan, 2020) is shaped through both direct and indirect channels. Direct channels include face-to-face discussions like communication during public events such as protests and other mass actions. The main indirect channel is the media which presents opinion poll results, polls conducted on the streets, general sentiment of news, etc. (Kim, 2017). The media sets and structures issues, thus shaping the agenda. They also assure an individual's selective perception and protect them from cognitive dissonance. Thus, stereotypes play a signifi- 
cant role in this process, triggering conformity, and making the discussed topic clearer (Shanahan et al., 2004).

The rise of SM platforms brought new challenges for SOS researchers. The research methodology for applying the theory to social media is varied, and the results are mixed. One of the first studies to address the topic revealed that the SOS continues spinning on Facebook, as the users' network on this platform is based mainly on their offline connections. Self-censorship also has a negative influence on the user's decision to leave a public comment on a specific topic (Gearhart, Zhang, 2014).

A positive correlation between the perceived opinion climate and the willingness to express a viewpoint has been revealed through meta-analyses; moreover, compared to traditional media, the spiraling process on digital platforms does not decrease (Matthes et al., 2018). There are some variations of the SOS effects on SM that are determined by common stereotypes about expressing a personal opinion in public (including cultural, religious, and gender determinants), as well as by the different level of freedom of speech and the Internet in the societies in comparison (Druzin, Gordon, 2018; Steen-Johnsen, Enjolras, 2016).

Chaudhry and Gruzd conclude that on Facebook, a predominantly non-anonymous and moderated platform, the vocal minorities are comfortable with expressing unpopular views, e.g., racist viewpoints, the fact that throws the SOS theory into question (2020). We would oppose this argument because the open expression of racist viewpoints in SM is unfortunately not a minority's behavioral model, but rather a trend if viewed in the context of wide-spread hate speech on the Internet (Alkiviadou, 2019; Guiora, Park, 2017). Some scholars have demonstrated that political discourse in SM is mainly irrational, emotional, and aggressive (Malaspina, 2014). In particular, Twitter publications expressing the majority's opinion have a higher level of emotionality than those of the minority (Luo et al., 2016).

Nuebaum and Krämer assume that various contextual factors such as audience familiarity, the communication channel, or the effect of negative sanctions on an individual's expectations if they represent the minority's view also determine an individual's fear of isolation (2016). Other studies point at opinion congruency as another factor affecting the willingness to express opinions via social media (Hampton et al., 2014).

People avoid speaking out when they notice that their opinion differs from the one prevalent among their online network or from the general public, and tend to search for information confirming their beliefs (Schulz, Roessler, 2012). Based on the users' online behavior, the SM algorithmic logic also plays a similar role in news consumption (Roy et al., 2017). When a user starts seeing homogenous content which usually interprets issues from one point of view, the algorithmic logic causes the risk of public opinion polarization. As a result, a diversity of opinions creates an isolated homogenous environment instead of stimulating discussions between opposite poles (Wilhelm, 2000).

Such homogenous environments (echo chambers) produce a fake diversity of opinion and surround a user with similar views, resulting in "pluralistic ignorance": a representative from each pole surrounded mainly by one point of view ascribes it to the majority 
(Liu, Famm, 2011). The homogenous SM environment contributes to the formation of a close circle of like-minded opinions. The risk of negative feedback also decreases the users' willingness to express an opinion (Gearhart, Zhang, 2015). The homogeneity of SM refers not only to the content but also to the sentiment of opinions.

Another important factor affecting the willingness to express an opinion via social media is the concern over self-presentation. SM has become one of the main platforms for an individual's self-expression and public image presentation. Any published information becomes a part of the users' digital identity, and functions as a symbol for their self-presentation. Although some researchers have revealed a positive correlation between self-presentation on Facebook and a willingness to express political views, everything depends on the purpose and character of self-presentation. If a user tends to create a self-presentation which aims to form a long-term positive public image, they will express opinions more actively. If self-presentation is protective and aims to avoid criticism, the user will avoid speaking in the conditions of high opinion diversity (Liu et al., 2017).

Finally, some authors point at the individual factors which might slightly shift the SOS logic of SM users toward some exceptions. These exceptions might be caused by a variety of factors, such as the user's personal attitude toward another's view if it is validated higher than the majority's opposite opinion climate (Fox, Holt, 2018); these factors need additional examination.

In order to test the SOS theory further as well as to identify the patterns and mechanisms that structure public opinion on current issues as popular topics discussed via SM, we will consider the features of public opinion on SM regarding the COVID-19 pandemic in the following section.

\section{COVID-19 on Social Media}

The global pandemic of COVID-19 reportedly started in December, 2019. It became globally known in January, 2020 (Shangguan et al., 2020), thus causing changes and bringing new challenges for all spheres of society world-wide. Almost all spheres of public life rapidly slowed down since a lockdown was announced in many countries, with forced distance work, on-line education, and travel bans. Such radical changes in people's lives brought an inevitable economic (Hotez, 2020), and social and psychological transformations (Prosser et al., 2020; Ali, Alharbi, 2020).

A growing number of COVID-19 consequences for national and global economies, public health, and everyday life (Gautam, Hens, 2020; Gautam et al., 2020) made the pandemic an actual and complex multidisciplinary research topic. Constantly-changing COVID-19 statistics (Pearce et al., 2020; Hoseinpour et al., 2020) as well as the limited effectiveness of national policies for tackling the disease (Law et al., 2020), made COVID-19 "invisible" and unpredictable. Accordingly, a systemic approach to its study might help better understand not only its biological roots, but also its multilevel dynamics including socio-psychological causes of its spread and its consequences. In this section, we are go- 
ing to address some structural peculiarities of public opinion on COVID-19 as reflected in SM.

The COVID-19 news spread in the media much faster than the pandemic itself, capturing information spaces in societies where the pandemic had not yet been detected. In particular, in January, 2020 (the beginning of the pandemic), information on COVID-19 was found 27 times more often in the headlines and 23 times more often in articles of the print media than the name of the Ebola virus in the first month of its appearance in August, 2018 (Ducharme, 2020).

Similarly, the spread of SM-posts about COVID-19 was immediate. As the Gallup/ Knight Foundation reported in a survey conducted in April, 2020, 46\% of SM users in the US said that "almost all" or "most" of what they see on SM sites is about the pandemic, and an additional $37 \%$ said that "about half" is on COVID-19. Over two-thirds of SM users said that coronavirus-related posts from public officials (70\%) and news organizations $(68 \%)$ were "very" or "moderately" helpful; $57 \%$ said the same about posts from family members and friends, while fewer said so about posts from neighbors (43\%) (Ritter, 2020). Simultaneously, a growing number of studies on the SM-coverage of the pandemic appeared immediately after the massive spread of COVID-19.

According to studies conducted in China, the SM-coverage of COVID-19 has had a rather positive impact on the population in the case of (1) facilitation and distribution of new information to providers of medical and other assistance on the front lines; (2) the utilization of SM-platforms by healthcare leaders to directly communicate with the public, sharing information that was traditionally relegated to medical journals and hospital video sessions; and (3) helping healthcare providers identify trends and to prepare for surges in acuity (Gottlieb, Dyer, 2020). In particular, a group of active clinical mental health providers based in Wuhan, China, and familiar with Chinese culture utilized an existing SM platform (WeChat) immediately after the pandemic broke out, and voluntarily provided peer-to-peer psychological support to frontline healthcare providers in Wuhan, which was considered an effective crisis intervention experience (Cheng et al., 2020). WeChat, as the largest social media in China, was monitored for public discussions on the pandemic in order to reveal the main topics and emphases of public consideration (Lu, Zhang, 2020).

However, some studies show that the unregulated massive SM content on COVID-19 has spread rumors about the "real nature" and "real causes" of the pandemic, becoming a source for panic and a reason not to follow healthcare instructions. In particular, there is a positive correlation between the use of SM as a source of information about the pandemic and COVID-19 conspiracy beliefs. The negative association is identified between COVID-19 conspiracy beliefs ("the coronavirus may not exist", "its lethality has been exaggerated", "its symptoms may have a non-viral cause", and so on) and specific health-protective behaviors (Allington et al., 2021).

Although SM has been putting in efforts to combat COVID-19 misinformation across its platforms by fact checking and removing false claims or banning ads with pandemicrelated content and prioritizing it in search results and newsfeeds (Hutchinson, 2020; 
Ferry, 2020), such attempts still go hand-in-hand with the spread of rumors and unverified information. This is especially relevant when considering that fake information in SM spreads faster than in traditional media (Vosoughi et al., 2018).

The U.N. Secretary-General, António Guterres, called the COVID-19 media coverage a "pandemic of misinformation" (Worrall, 2020). Similarly, a massive spread of disinformation, panic, or an underestimation of the pandemic threat through SM has been called an "infodemic", which was defined as "the rapid spread of misinformation or fake news through social media platforms and other outlets" (Chong et al., 2020).

Among the negative consequences of the infodemic on SM are the social stigma around COVID-19 (Tasnim et al., 2020), loneliness (Banerjee, Rai, 2020), the personification of the public discourse on the pandemic based on individual cases, the irresponsibility of information broadcasted and the disruption of social trust (Tulchinskii, 2020), as well as the dissemination of drugs not prescribed or officially approved (Carius, Schauer, 2020).

Despite a growing actualization of the issues regarding SM use during the pandemic, we did not find any study which would explore SOS effects in the public discourse in SM regarding COVID-19. The research question we are going to examine in the next section is whether the fear of isolation, the domination of majority thinking, and other elements of the SOS logic have influenced COVID-19 public discourses on SNS.

The main interest of the study is to explain the dynamics and mechanisms of virtual communication regarding COVID-19. We do not have the objective to explain the real (offline) behavior of the society in the pandemic, including such determinants as the level of trust in public policies and institutions, or models of conduct in public places (transport, cafes), etc. Knowing the statistics of official rules violations during the pandemic helps to reveal the structure of virtual communication regarding the public attitudes towards COVID-19 and, in particular, to understand why the majority prefers to agree with official statements but behave differently.

The spiral effect is considered when we talk about the influence of a friendly/unfriendly climate of opinion on the personal mindset and communicative activity of a user. Combining the secondary analysis of the field data collected in the period of the research with our survey, we look at the influence of the Facebook climate of opinion on the Armenian users involved in online-communication on COVID-19. In relying on the SOS theory described above and applied to social media platforms, we look at the correlation between the perceived climate of opinion and the willingness to express one's own judgments. In particular, we examine the theoretical statement that people avoid speaking out when they notice that their opinion differs from the one adopted by their online network or by the general public. The spiral effect appears when the homogenous social media environment contributes to the formation of a close circle of like-minded opinions. We examine this process through Facebook users' preferences to communicate or react to "friends" and avoid open communication with non-friends. The larger the group of respondents preferring to communicate inside the circle of like-minded "friends", the stronger the climate of opinion influences their own mindsets. Consequently, the spiral 
effect here is not merely a common fact but a characteristic of communication, and, following the SOS theory, we also try to reveal a correlation between self-presentation on Facebook and the willingness to express one's own views on popular discursive topics (COVIDd-19).

\section{COVID-19 Perceived by Armenian Facebook Users: Research Methodology}

Armenia is a post-Soviet Christian country with a population of approximately 3 million people ${ }^{1}$ bordering Georgia, Azerbaijan, Turkey, and Iran. ${ }^{2}$ According to the typology of the societies in terms of collectivism vs. individualism as developed by Geert Hofstede (2011), Armenia is a collectivist society with prevalence of "We" over "I", and of group thinking over individual choice. ${ }^{3}$ There are few existing comparative studies on the SOS logic among SM users in individualist and collectivist societies which confirm the hypothesis that the significance of the majority's opinion regarding one's own actions (comments, posts, or likes) is higher in collectivist than in individualist cultures (Huang, 2005). The prevailing collectivist values might serve as another mechanism of public opinion consolidation around popular frames of thinking and behavior in COVID-19 conditions, which makes the Armenian case-study useful for understanding the logic of thinking in other collectivist societies.

Thus, this is the first study of public perceptions regarding the pandemic among SM users in Armenia in terms of SOS, and the first test of the SOS theory applied to Armenian society. It might also contribute to the studies of public perceptions and SMcommunications within the context of the SOS theory and collectivist values. Revealing the mechanisms of SM-based public perceptions regarding COVID-19 in Armenia might also help to better understand the dynamics of public opinion in other countries with similar attitudes.

In our study, we have made an attempt to assess the level of trust toward various sources and channels of information on the pandemic among the Armenian users, including SM; to identify the attitudes of Facebook users in Armenia regarding the origins and the level of the COVID-19 threat, as well as toward policies adopted by the Armenian Government against the pandemic; to examine the reasons for such attitudes, including the significance of the majority's opinion in determining individual choice; to analyze the intensity of various models of communicating the pandemic as practiced by Armenian Facebook users, and to assess the role of the opinion climate perceived as either supportive or negative for an individual communicative action.

The field part of the research consisted of two stages. During the first stage, a secondary analysis of the four mass surveys conducted in Armenia regarding public perceptions

1. Economic and Financial Data for the Republic of Armenia. Statistical Committee of the Republic of Armenia. Available at: https://armstat.am/nsdp/ (accessed 12 October 2020).

2. Armenia Country Profile. BBC, 18 November 2020. Available at: https://www.bbc.com/news/worldeurope-17398605 (accessed 20 November 2020).

3. Hofstede Insights. Country Profile: Armenia. Available at: https://www.hofstede-insights.com/countrycomparison/armenia/ (accessed 17 June 2020). 
on COVID-19 has been implemented. ${ }^{4}$ During the second stage of data collection, an online survey was conducted via Facebook (as the most popular SM in Armenia) in using Google forms (from July 1 to August 30, 2020). The survey was conducted when the number of COVID-19 cases in Armenia was on the rise. ${ }^{5}$ In the period of the survey (JulyAugust 2020), about 1,761,000 users have been on Facebook, ${ }^{6}$ which makes about $60 \%$ of the Armenian population and $75 \%$ of social media users in Armenia. ${ }^{7}$ The questionnaire was designed in Armenian and placed in a free access so that respondents have been chosen according to their interest in participation, and were not limited by friends or friends of friends of the interviewers as Facebook users. The survey was stopped when responses were no longer received. There were 610 Armenian Facebook users who participated in the survey. The data collected was processed by means of SPSS software, Version 21.0 for Windows (IBM SPSS Statistics).

Among the respondents of the survey conducted in terms of the study, 49\% are male and $51 \%$ are female, most of them are young people $(80 \%), 19 \%$ were from the middleaged population, and $1 \%$ are those were over 56 years old; $66 \%$ are inhabitants of the capital Yerevan, $18 \%$ are urban, and $11 \%$ were rural residents of Armenia. The $4 \%$ of Armenian respondents who addressed the survey but lived outside their home country at the moment are excluded from the analysis. These figures reflect the gender proportions of Facebook users exactly in Armenia ( $51 \%$ are women and $49 \%$ are men). The respondents' proportions by age are the same as those of Armenian Facebook users; the younger population is a majority $(57 \%)$, while people over 55 years old comprise a minority $(4 \%)$ of users. ${ }^{8}$

There are some limitations for this survey which should be considered when interpreting the results. The sample size, as well as the fact that only Facebook users were included in it, does not allow the results to be applied to the whole of the Armenian population. However, this study sheds light on the mechanisms of public opinion and communicative behavior on social media during the global pandemic.

4. Assessing the Level of Awareness About and the Impact of the Novel Coronavirus in Armenia (2020). Final Report of the Online Survey. CRRC Armenia. Available at: http://www.crrc.am/wp-content/ uploads/2019/03/COVID_CRRC_Survey_Final_Report_Eng.pdf (accessed 5 July 2020); Public Attitudes towards Situation around COVID-19 in Armenia. Initiative group of YSU Faculty of Sociology alumni network. Yerevan, 2020 (the report circulated among the members of the network); Public Opinion Survey: Residents of Armenia. Center for Insights in Survey Research, 2020. Available at: https://www.iri.org/sites/default/ files/7.14.2020_armenia_survey_on_COVID_19_response.pdf (accessed 8 July 2020); Usage of Mobile Messenger Applications in Armenia. R-Insights Research Company, 2020. Available at: https://r-insights.am/en/ insights/mobile-app-usage-in-Armenia (accessed 12 July 2020).

5.Armenia: Coronavirus cases. Worldometer, 2020. Available at: https://www.worldometers.info/coronavirus/country/armenia/ (accessed 12 August, 2020).

6. Facebook users in Armenia, July 2020. Available at: https://napoleoncat.com/stats/facebook-users-inarmenia/2020/07 (accessed 01.07.2021).

7. Available at: https://gs.statcounter.com/social-media-stats/all/armenia (accessed 01.07.2021).

8. Facebook users in Armenia, July 2020. Available at: https://napoleoncat.com/stats/facebook-users-inarmenia/2020/o7 (accessed 01.07.2021). 


\section{Research Findings and Discussion}

Like many other countries, Armenia suffered heavily from the COVID-19 pandemic, registering the highest level of deaths proportional to the regional share of its population (Mejlumyan, 2020). Communications on COVID-19 were held in parallel by several state organizations: the Government, the Commandant's office, ${ }^{9}$ the Ministries of Health, Labor, and Social Affairs, Economics, and Foreign Affairs. The first imported COVID-19 case in the country was registered on March 1, 2020. The Government declared a onemonth state of emergency on 16 March; it has been extended five times since (Hovhannisyan, 2020). During the state of emergency, different channels including live and status updates on SM platforms, SMS messages, and press conferences for media representatives have been used.

The Government of Armenia aimed to control the information flow at the early stages of the lockdown, trying to ban any non-official information on COVID-19 cases by declaring a state of emergency. ${ }^{10}$ This attempt at the regulation of the information sphere failed, raising debates on media censorship.

At the same time, the absence of a central information source caused many difficulties for proper media functioning as well. Among the main reasons contributing to the rise of COVID-19 misinformation in Armenian media is an insufficient level of medialiteracy and public fears regarding the pandemic, the media's and some other actors aim to sensationalize the topic of the pandemic, intentional manipulations, as well as local entrepreneurs trying to save their business by urging people not to take the pandemic seriously and to continue using their services (Grigoryan, 2020). Besides, there has been a problem concerning the systematic delivery of messages, their accessibility, and perception by different groups in society. As a consequence, misinformation and fake news quickly spread through the society, selling fictions and conspiracy theories regarding the "fake nature" of the pandemic or rumors about the "microchipping of society" in the form of the vaccination. ${ }^{11}$

Analyses of the studies conducted by partner organizations mentioned above show the Web as the most popular source of COVID-19 information in Armenia ("Public attitudes towards situation," 2020), while its most trusted sources are the officials responsible for the pandemic ("Assessing the level," 2020). Our own survey supports these conclusions demonstrating that Facebook posts by officials are the most trusted news sources regarding COVID-19 in Armenia; $45 \%$ rather trust and 12\% totally trust the public officials. The experts' opinion is another trusted news source on the pandemic, at $47 \%$. Meanwhile, the

9. A state body established to coordinate policy implementation under emergency: Commandant's Office Holds Regular Meeting, 25 March 2020. Available at: https://www.gov.am/en/news/item/9765/ (accessed 26 November 2021).

10. On a State of Emergency. Government of Armenia, 2020. Available at: https://www.e-gov.am/govdecrees/item/33564/ (accessed 16 June 2020).

11. Ghazanchyan S. Armenian Health Minister worried about COVID-19 conspiracy theories running rampant. Public Radio of Armenia, 15 May 2020. Available at: https://en.armradio.am/2020/05/18/armenianhealth-minister-worried-about-COVID-19-conspiracy-theories-running-rampant/ (accessed 25 July 2020). 
least trusted news sources regarding COVID-19 are Armenian newspapers (33\% totally do not trust) and TV (29\% totally do not trust). Influencers also have a low level of trust; only $2 \%$ totally trust them. In case of radio, Armenian and foreign channels are trusted almost equally (5\% totally trust, $40 \%$ rather trust and $6 \%$ totally trust, and $36 \%$ rather trust accordingly).

It is remarkable that there is almost no difference between real and virtual friends (on Facebook) as source of information regarding the pandemic for Armenian respondents. Friends/relatives as well as "friends" on Facebook are the least trusted (15\%) pandemicrelated news sources for respondents in Armenia. The respondents trust Armenian online sources slightly less (6\% totally trust and $35 \%$ rather trust) than foreign websites (6\% totally trust and $56 \%$ rather trust), and only $8 \%$ of the respondents indicated that they do not trust any information source. These results contradict the idea of the Armenian society being collectivist. Although, considering that the majority of our respondents are young people, we can assume that the younger generation acts in a more individualistic and rational way while choosing trusted sources of information.

One of the reasons why the majority in Armenia trust official sources of pandemic information and expect that state policies should be effective might be the specifics of public attitudes toward the role of the state in Armenia. After the collapse of the Soviet Union of which Armenia was a part, the majority of its population continued to consider the state as a paternalistic entity in society ("Public Perceptions," 2017). According to public expectations, the state is obliged to take care of it and, accordingly, must take necessary pandemic measures, while society does not consider itself to be an equally responsible and active participant in the measures taken. Accordingly, official statements about the pandemic, including those in SM channels, are in the spotlight of a significant part of the population. In this regard, the role of an uncertain and fast-changing information environment (accessible sources and content of information on the problem) should also be taken into consideration.

During the first months of the pandemic, people were constantly receiving diverse and often contradictory information about the virus, its origin, modes of transmission, means of protection, etc. The lack of knowledge and uncertainty of information decreases the value of each piece of information, thus making officials the most reliable sources. Such uncertainty also renders it difficult to define the majority's opinion, which makes the spiral of silence spin in a specific way; people keep silent not because they are afraid to contradict the majority's opinion, but because they are uncertain about what the majority really thinks.

It is interesting to see that trust toward official sources of information regarding COVID-19 as expressed by the majority of respondents is also reflected in the support for the measures taken by the Government. The same group of respondents also highly validated the steps taken by the Government in tackling the pandemic. According to data collected, $43 \%$ of respondents assessed the Government's response to the pandemic to be the most effective and proper, while $25 \%$ of respondents thought it was effective only in the beginning and $32 \%$ criticized the state policies toward the pandemic as ineffective. 
Similarly, we see the majority's support of all lockdown measures, including travel and public places bans; $38 \%$ of respondents think that these measures should be kept until the virus is neutralized, and $53 \%$ say lockdown measures should be canceled simultaneously with the decrease of confirmed cases. Only $9 \%$ think that all measures should be canceled as soon as possible. There are more supporters of all lockdown measures maintenance among women $(43 \%)$ than among men $(31 \%)$.

The considerable correlation between trust in the official information regarding COVID-19 (as broadcast through traditional and social media channels) and support for state policies toward the pandemic demonstrates that those consuming official information also tend to agree and demonstrate loyalty to state policies. Trust toward non-official sources of information is correlated with rather critical views of the Government, if compared to a conformist view.

The SOS effect regarding the conformity of public perception and communicative behavior as demonstratively synchronized with the official position is supported here by the findings on what the respondents say they have been doing in the pandemic. The vast majority of the respondents of our survey $(67 \%)$ say they have been following official norms and rules set by the state while only a minority (20\%) oppose them openly, confessing that they behaved according to their own opinion even if it contradicted the public one. Women seem to be less likely to behave according to their own opinion (14\%) than men (26\%) regarding the pandemic requirements, which is also an indication of the collectivist and traditionalist traits in Armenian society.

Most of the respondents assure that they have been staying home ( $7 \%$ say they never left home, and $60 \%$ left home only in some urgent cases); $21 \%$ say they have been leaving for a job, and only $12 \%$ say they have been leaving home whenever they wanted. Again, the majority of the surveyed Facebook users in Armenia confirm their loyalty to state COVID-19 policies and restriction rules, stating that they have been behaving accordingly.

Similar responses are received by other surveys with larger (national) sampling conducted during the pandemic, and listed here. Most of the respondents state they have been following the official requirements; $11 \%$ self-isolated and never left their homes, $46 \%$ left their homes only in case of emergency, $29 \%$ was working/studying from home, etc. ${ }^{12}$

Meanwhile, according to the numerous statements made by the prime-minister of Armenia and the Government officials responsible for tackling the virus, public behavior during the pandemic has been the main cause of the unprecedented spread of the disease. According to these statements, people avoid wearing masks and gloves and maintaining social distance; they go outside and crowd in public places in masses, etc. ${ }^{13}$ As we can see from the mass survey conducted by the CRRC and listed here, a majority of respondents

12. Public Attitudes towards the Situation around COVID-19 in Armenia; the Initiative group of the YSU Faculty of Sociology alumni network, Yerevan, 2020.

13. Remarks Delivered by Prime Minister Nikol Pashinyan at the National Assembly Debate on Declaring a State of Emergency in the Republic of Armenia. The Prime Minister of the Republic of Armenia, 16 March 2020. Available at: https://www.primeminister.am/en/statements-and-messages/item/2020/03/16/Nikol-Pashinyan-National-Assambly/ (accessed 13 June 2020). 
have been well aware about possible sanctions for the misconduct; $41 \%$ indicate administrative punishment, $10 \%$ specify criminal punishment, and $40 \%$ mention both. ${ }^{14}$

As a matter of fact, Armenia has demonstrated the highest regional infection rate, being among the countries most heavily affected by the pandemic, ${ }^{15}$ which means that there has been a massive and regular violation of state rules by the Armenian population. Our everyday observations also confirm the Government's official blames everyday customs and behavioral patterns of society. Despite the high rate of transmission, Armenians mostly behaved as if there was no threat at all. They were hugging and kissing each other hello and goodbye on the streets and in offices, spending their leisure time in crowded public places such as restaurants and cafes, or visiting big family events like weddings or baptisms. Similarly, the Government representatives dealing with the threat have been spotted at public events without keeping a social distance or wearing masks.

What we are witnessing here is the majority's confirmation of their behavior as corresponding to official requirements announced through official sources of information, while in reality, the majority's behavior has actually been different and even contradictory to state policies. The majority states that it obeys the rules, but on the individual level, people do the opposite. Being under the pressure of official restrictions, those who actually violate the rules prefer not to declare it openly, either keeping silent or proclaiming their loyalty to these rules, including their answers in public polls and surveys.

Although trusting official sources of pandemic information, the majority of the population breaks the rules and restrictions; the fact of massive violations of COVID-19 official rules and restrictions, including violations by those officials who decide on these restrictions, demonstrates public misconduct during the pandemic that is similarly typical for elites and the majority of the population. The question of why people violated the rules, even while being well aware of the possible negative outcomes, and continuing their everyday customs such as hugging and kissing on the streets, visiting public places without being protected. etc., relates to other research fields like cultural anthropology, and is outside the scope of this study. On the other hand, most respondents prefer to confirm their loyalty to and agree with state rules and limitations when discussing the topic online and, in particular, addressing surveys, which directly refers to the fear of communicative isolation described by the SOS theory.

As with the fear of isolation component, the fear of virtual and/or real negative sanctions determines public behavior (including communicative behavior on virtual social network sites). According to Neubaum and Krämer, people tend to express a deviant opinion in an offline environment for unfamiliar audiences more often than they do on Facebook. The authors explain this by negative sanctions and the easiness of their application on online-based platforms (2016). In the case of Armenia, the fear of a negative

14. Assessing the Level of Awareness About and the Impact of the Novel Coronavirus in Armenia (2020). Final Report of the Online Survey. CRRC Armenia. Available at: http://www.crrc.am/wp-content/ uploads/2019/03/COVID_CRRC_Survey_Final_Report_Eng.pdf (accessed 5 July 2020).

15. Corona Tracker, Armenia Overview. Available at: https://www.coronatracker.com/country/armenia/ (accessed 12 July 2020). 
communicative reaction and administrative sanctions has its role and limitations, but communicative sanctions (online) tend to prevail over administrative sanctions (offline).

Addressing the question about what the pandemic is about, the majority (58\%) of respondents say that COVID-19 is a new and dangerous disease of a natural origin. Actually, this is the group of respondents who trust official sources and follow official statements. The results show that $35 \%$ of respondents say that the virus was created in labs; most of them (33\%) state that the aim is to decrease the population on Earth. The statement that COVID-19 is artificially created to kill people intentionally is popular among $38 \%$ of female and $27 \%$ of male respondents in Armenia; this shows that men prefer interpretations in terms of an infodemic less than women. Next, $3 \%$ of all respondents say that Coronavirus is real, but not as dangerous as presented by the media, while $2 \%$ do not believe in the existence of the pandemic at all.

In another part of the study, we tried to describe Facebook users in Armenia as COVID-19 information sources, as well as revealing their communicative strategies and behavior. We intended to examine two factors mentioned in the theoretical part of the paper. According to the first factor, the homogenous social media environment contributes to the formation of a close circle of like-minded viewpoints, encouraging a user to express their own opinion only if it is similar to the mindset of this circle. The second hypothesis connects the communicative strategies of SM users with their striving toward self-presentation. If some users try to create a long-term positive public image relying on their SM self-presentation, they express an opinion more actively, while preferring to keep silent in the conditions of high opinion diversity in order to avoid criticism leading to isolation.

We found that the option to like/react on others' posts is the most preferable mode of constantly-practiced communicative behavior (33\%) among Armenian users on Facebook in the case of COVID-19. Commenting and sharing are among the less practiced forms of online activity. Only 10\% have reported that they leave comments often, while $8 \%$ said that they often share others' posts. However, $50 \%$ of those who report the prevalence of an opposite opinion among their Facebook friends avoid posting comments. Besides, $37 \%$ of those who identify the climate of opinion among their Facebook friends as rather different from the opposite one prefer not to post comments on their own, while $26 \%$ of respondents say that they are neither interested in others' opinions, nor in posting their own.

What we see here is that the majority of Armenian Facebook users prefer self-presentation to an absolutely indifferent behavior. Moreover, they prefer protective self-presentation with the aim to avoid criticism. On the other hand, the majority prefers the most passive and rather neutral way of activity such as liking and following to posting and commenting. The latter strategy is rather challenging and risky: there is an obvious portion of fear of criticism and isolation among the users who would prefer not to comment in an opinion environment, which is not only opposite but diverse.

We realized that women in Armenia are a bit less worried about their communicative reputation than men. Women are more active commenters than men ( $55 \%$ to $49 \%$ ); they 
share (54\% to $52 \%)$ as well as posting and updating their status on Facebook more often than men ( $58 \%$ to $53 \%$, accordingly).

However, women are less active commenters to strangers' posts (54\%) than men are $(67 \%)$. We tend to explain this specific by the fact that women comment more actively in their well-known and predictable environments, but refrain from experiments and risks with strangers. This type of behavior might be explained in terms of a set of unwritten rules regarding public expectations toward men and women in any traditional society. In such societies, women are more affected by some informal social control than men, including communication with strangers in general which is more controlled offline than online. What we witness online is a combination of informal public customs and SOS logic. Women are more active communicators in general, but being more affected by informal public control than men, they prefer to limit their contacts by frames of a familiar audience. The SOS logic is present here in a wider socio-cultural context.

The most preferable situation wherein the respondents are willing to discuss COVID-19-related topics is a real (offline) gathering or party (45\% very likely, $32 \%$ most likely), while the least preferable situation is the SM-discussion on the pandemic with strangers (10\% very likely and $12 \%$ most likely). This means that most of the users prefer not to risk their public image and online/offline reputation, while some "friends" on Facebook are friends offline. Accordingly, a group of real people (friends) at a party sounds more predictable in a sense of affinity in opinions than the unpredictable environment of virtual strangers and even virtual "friends".

\section{Conclusions}

The paper presents the first attempt to study the communicative behavior of Facebook users in Armenia in terms of the Spiral of Silence Theory, using the actual case of COVID-19 as the popular social media topic. As a collectivist society according to Hofstede typology, Armenia demonstrates an example of communicative behavior in SM which might be applicable to other societies of this type.

The study confirms three elements of the SOS theory as applied to the communicative behavior of Facebook users in Armenia. First, we identified a gap between the majority's opinion about state policies and official requirements of public conduct during the pandemic and actual mass behavior. The majority prefers not to contradict state policies and requirements in public discussions on Facebook; they report their loyalty to the officially stated rules as well as appropriate behavior while being surveyed. On the other hand, according to the state bodies responsible for tackling the pandemic, inappropriate public behavior and massive violations of lockdown rules are considered to be the main cause for the spread of the virus in Armenia.

According to the SOS logic, people in the majority are well informed about public conduct requirements during the pandemic but do not follow them, and, being aware of sanctions, they hide their real opinion, either preferring to openly agree with the official position, or silently breaking the rules (keep silence). 
Second, there is a correlation between users' perceptions regarding the opinion environment of their Facebook friends and their preference for posting on their opinion, as well as commenting on others' posts. If the communicative environment is perceived as rather contradictory to the user's opinion and as diverse in a lesser sense, the essential part of the users surveyed prefer not to post and not to comment on others' opinion (keep silence). Female Facebook users in Armenia are more active commenters than men, but their activity is mostly limited to the circle of familiar users whose opinion, compared to that of the strangers, is more predictable in advance as well as being non-threatening to their personal reputation.

Third, self-presentation is a preferable strategy of Facebook communicative activities among Armenian users who would prefer not to risk their reputation and not to put their opinion under an open and massive critique. Accordingly, in order to express their own opinions freely and comment on that of others, most of the users surveyed would prefer an offline and familiar (predictable) environment of real friends, while online communication with strangers is the least comfortable situation which would prevent Armenian users from free expression.

Being the first attempt to use the SOS theory to explore the mechanisms affecting COVID-19 public opinion in social media, the results of this survey can be useful for future studies of the public response and collective behavior in such challenging situations like a global pandemic.

\section{References}

Ali I., Alharbi O. (2020) COVID-19: Disease, Management, Treatment, and Social Impact. Science of the Total Environment, no 1, art. 138861.

Alkiviadou N. (2019) Hate Speech on Social Media Networks: Towards a Regulatory Framework? Information and Communications Technology Law, vol. 28, no 1, pp. 1935.

Allington D., Duffy B., Wessely S., Dhavan N., Rubin J. (2021) Health-Protective Behaviour, Social Media Usage and Conspiracy Belief during the COVID-19 Public Health Emergency. Psychological Medicine, vol. 51, no 10, pp. 1763-1769.

Banerjee D., Rai M. (2020) Social Isolation in COVID-19: The Impact of Loneliness. International Journal of Social Psychiatry, vol. 66, no 6, pp. 525-527.

Breuer A. (2012) The Role of Social Media in Mobilizing Political Protest: evidence from the Tunisian Revolution (Discussion Paper), Deutsches Institut für Entwicklungspolitik.

Brouwer A., Bartels E. (2014) Arab Spring in Morocco: Social Media and the 20 February Movement. Africa Focus, vol. 27, no 2, pp. 9-22.

Carius B., Schauer S. (2020) Ibuprofen During the COVID-19 Pandemic: Social Media Precautions and Implications. Western Journal of Emergency Medicine, vol. 21, no 3, pp. 497-498.

Carr C. T., Hayes R. A. (2015) Social Media: Defining, Developing, and Divining. Atlantic Journal of Communication, vol. 23, no 1, pp. 46-65. 
Chaudhry I., Gruzd A. (2020) Expressing and Challenging Racist Discourse on Facebook: How Social Media Weaken the "Spiral of Silence" Theory: Countering Racist Discourse on Facebook. Policy and Internet, no 12, pp. 88-108.

Cheng P., Xia G., Pang P., Wu B., Jiang W., Li Y., Wang M., Ling Q., Chang X., Wang J., Dai X., Lin X., Bi X. (2020) COVID-19 Epidemic Peer Support and Crisis Intervention via Social Media. Community Mental Health Journal, vol. 56, pp. 786-792.

Chong Y., Cheng H., Chan H., Chien W., Wong S. (2020) COVID-19 Pandemic, Infodemic and the Role of eHealth Literacy. International Journal of Nursing Studies, vol. 108 , art. 103644 .

Comninos A. (2011) Twitter Revolutions and Cyber Crackdowns User-Generated Content and Social Networking in the Arab Spring and Beyond. Available at: https:// www.apc.org/sites/default/files/AlexComninos_MobileInternet.pdf (accessed 13 June 2020).

de Zúñiga H. G., Jung N., Valenzuela S. (2012) Social Media Use for News and Individuals' Social Capital, Civic Engagement and Political Participation. Journal of ComputerMediated Communication, vol. 17, no 3, pp. 319-336.

Druzin B., Gordon G. S. (2018) Authoritarianism and the Internet. Law and Social Inquiry, vol. 43, no 4, pp. 1427-1457.

Fox J., Holt L.F. (2018) Fear of Isolation and Perceived Affordances: The Spiral of Silence on Social Networking Sites Regarding Police Discrimination. Mass Communication and Society, vol. 21, no 5, pp. 533-554.

Friedman T. L. (2006) The World is Flat: A Brief History of the Twenty-First Century, New York: Farrar, Straus \& Giroux.

Gautam S., Hens L. (2020) COVID-19: Impact by and on the Environment, Health and Economy. Environment, Development and Sustainability, vol. 22, no 6, pp. 4953-4954.

Gautam M., Thakrar A., Akinyemi E. (2020) Current and Future Challenges in the Delivery of Mental Healthcare during COVID-19. SN Comprehensive Clinical Medicine, vol. 2 , no 7, pp. 865-870.

Gearhart Sh., Zhang W. (2014) Gay Bullying and Online Opinion Expression: Testing Spiral of Silence in the Social Media Environment. Social Science Computer Review, vol. 32, no 1, pp. 18-36.

Gearhart Sh., Zhang W. (2015) “Was It Something I Said?” "No, It Was Something You Posted!" A Study of the Spiral of Silence Theory in Social Media Contexts. Cyberpsychology, Behavior and Social Networking, vol. 18, no 4, pp. 208-213.

Gottlieb M., Dyer S. (2020) Information and Disinformation: Social Media in the COVID-19 Crisis. Academic Emergency Medicine, vol. 27, no 7, pp. 640-641.

Grigoryan G. (2020) The Armenian Media in Times of the Pandemic. Available at: https:// orbeli.am/hy/post/466/2020-06-08/ (accessed 9 July 2020).

Guiora A., Park E. A. (2017) Hate Speech on Social Media. Philosophia, vol. 45, no 3, pp. 957-971.

Hampton K., Rainie L., Lu W., Dwyer M., Shin I., Purcell K. (2014) Social Media and the Spiral of Silence (Survey Report), Pew Research Center. Available at: https://www. 
pewresearch.org/internet/2014/08/26/social-media-and-the-spiral-of-silence/ (accessed 28 July 2020).

Hofstede G. (2011) Dimensionalizing Cultures: The Hofstede Model in Context. Online Readings in Psychology and Culture, vol. 2, no 1, art. 8.

Hoseinpour D.A., Alizadeh M., Derakhshan P., Babazadeh P., Jahandideh A. (2020) Understanding Epidemic Data and Statistics: A Case Study of COVID-19. Medical Virology, vol. 92, no 7, pp. 868-882.

Hotez P. J. (2020) Poverty and the Impact of COVID-19: The Blue-Marble Health Approach, Baltimore: Johns Hopkins University Press.

Hovhannisyan N. (2020) Armenia Extends Coronavirus State of Emergency until June 13. Reuters, 14 May. Available at: https://www.reuters.com/article/us-health-coronavirusarmenia-emergency-idUSKBN22Q14X (accessed 15 May 2020).

Huang H. (2005) A Cross-Cultural Test of the Spiral of Silence. International Journal of Public Opinion Research, vol. 17, no 3, pp. 324-345.

Hutchinson A. (2020) Facebook Has Taken a Harder Stance Against COVID-19 Misinformation - So Why Can't It Do That for Everything. Social Media Today, 26 March. Available at: https://www.socialmediatoday.com/news/facebook-has-taken-a-harderstance-against-COVID-19-misinformation-so-why/574895/ (accessed 30 April 2020).

Kim S. H. (2017) Spiral of Silence: Fear of Isolation and Willingness to Speak Out. The International Encyclopedia of Media Effects. Available at: https://onlinelibrary.wiley. com/doi/10.1002/9781118783764.wbiemeo037 (accessed 30 April 2020).

Law S., Wingnang A.L., Xu Ch. (2020) Severe Acute Respiratory Syndrome (SARS) and Coronavirus Disease-2019 (COVID-19): From Causes to Preventions in Hong Kong. International Journal of Infectious Diseases, vol. 94, pp. 56-163.

Lee J., Yan W. (2020) The Role of Interdependent Self-Value and Opinion Climate in Promoting Online Discussion. Computers in Human Behavior, no 103, pp. 226-235.

Liu Y., Raymond J., Xi R. (2017) Are People Willing to Share Their Political Opinions on Facebook? Exploring Roles of Self-Presentational Concern in Spiral of Silence. Computers in Human Behavior, vol. 76, pp. 294-302.

Liu X., Fahmy Sh. (2011) Exploring the Spiral of Silence in the Virtual World: Individuals' Willingness to Express Personal Opinions in Online Versus Offline Settings. Journal of Media and Communication Studies, vol. 3, no 2, pp. 45-57.

Lu Y., Zhang L. (2020) Social Media WeChat Infers the Development Trend of COVID-19. Journal of Infection, vol. 81, pp. 82-83.

Luo L., Li M., Wang Q., Xue Y., Liu Ch., Wang Zh. (2016) Spiral of Silence in Social Networks: A Data-driven Approach. Available at: https://ieeexplore.ieee.org/document/7752359 (accessed 12 May 2020).

Malaspina C. (2014) The Spiral of Silence and Social Media: Analyzing Noelle-Neumann's Phenomenon Application on the Web during the Italian Political Elections of 2013. Available at: https://www.lse.ac.uk/media-and-communications/assets/documents/ research/msc-dissertations/2013/Malaspina.pdf (accessed 13 May 2020). 
Matthes J., Knoll J., von Sikorski Ch. (2018). The "Spiral of Silence" Revisited: A MetaAnalysis on the Relationship Between Perceptions of Opinion Support and Political Opinion Expression. Communication Research, vol. 45, no 1, pp. 3-33.

Mejlumyan A. (2020) Armenian Officials Rule Out New Lockdown Even as COVID Worsens. Available at: https://eurasianet.org/armenian-officials-rule-out-new-lockdown-even-as-COVID-worsens (accessed 30 June 2020).

Metzger M., Tucker J. (2017) Social Media and EuroMaidan: A Review Essay. Slavic Review, vol. 76, no 1, pp. 169-191.

Neubaum G., Krämer N. (2018) What Do We Fear? Expected Sanctions for Expressing Minority Opinions in Offline and Online Communication. Communication Research, vol. 45, no 2, pp. 139-164.

Neuwirth K., Frederick E., Mayo Ch. (2007) The Spiral of Silence and Fear of Isolation. Journal of Communication, vol. 57, no 3, pp. 450-468.

Ohlsson J., Lindell J., Arkhede S. (2017) A Matter of Cultural Distinction: News Consumption in the Online Media Landscape. European Journal of Communication, vol. 32, no 2, pp. 116-130.

Pearce N., Vandenbroucke J. P., VanderWeele T. J., Greenland S. (2020) Accurate Statistics on COVID-19 are Essential for Policy Guidance and Decisions. American Journal of Public Health, vol. 110, no 7, pp. 949-951.

Prosser A. M. B., Judge M., Bolderdijk J. W., Blackwood L., Kurz T. (2020) "Distancers" and "Non-distancers"? The Potential Social Psychological Impact of Moralizing COVID-19 Mitigating Practices on Sustained Behaviour Change. British Journal of Social Psychology, vol. 59, no 3, pp. 653-662.

Ritter Z. (2020) Americans Use Social Media for COVID-19. Available at: https://news. gallup.com/poll/31136o/americans-social-media-COVID-information-connection. aspx (accessed 30 May 2020).

Roy A., Huh J., Pfeuffer A., Srivastava J. (2017) Development of Trust Scores in Social Media (TSM) Algorithm and Application to Advertising Practice and Research. Journal of Advertising, vol. 46, no 2, pp. 269-282.

Schulz A., Roessler P. (2012) The Spiral of Silence and the Internet: Selection of Online Content and the Perception of the Public Opinion Climate in Computer-Mediated Communication Environment. International Journal of Public Opinion Research, vol. 24, no 3, pp. 346-367.

Shangguan Z., Mark Y. W., Sun W. (2020) What Caused the Outbreak of COVID-19 in China: From the Perspective of Crisis Management. International Journal of Environmental Research and Public Health, vol. 17, no 9, pp. 1-16.

Shanahan J., Scheufele D., Yang F., Hizi S. (2004) Cultivation and Spiral of Silence Effects: The Case of Smoking. Mass Communication and Society, vol. 7, no 4, pp. 413-428.

Simpson C. (1996) Elisabeth Noelle-Neumann's "Spiral of Silence" and the Historical Context of Communication Theory. Journal of Communication, vol. 46, no 3, pp. 149-173.

Steen-Johnsen K., Enjolras B. (2016) The Fear of Offending: Social Norms and Freedom of Expression. Society, vol. 53, no 4, pp. 352-362. 
Tasnim S., Hossain M., Mazumder H. (2020) Impact of Rumors and Misinformation on COVID-19 in Social Media. Journal of Preventive Medicine and Public Health, vol. 53, no 3, pp. 171-174.

Tulchinskii G. L. (2020) The Dynamics of Public Discourse during the Coronavirus Pandemic: A Request for Responsibility. Russian Journal of Communication, vol. 12, no 3, pp. 193-214.

van Dijck J., Poell Th. (2013) Understanding Social Media Logic. Media and Communication, vol. 1, no 1, pp. 2-14.

Vosoughi S., Roy D., Aral S. (2018) The Spread of True and False News Online. Science, no 359, pp. 1146-1151.

Wilhelm A. (2000) Democracy in the Digital Age: Challenges to Political Life in Cyberspace, London: Routledge.

Worrall R. (2020) Battling the "Pandemic of Misinformation. Available at: https://news. harvard.edu/gazette/story/2020/05/social-media-used-to-spread-create-COVID19-falsehoods/ (accessed 13 July 2020).

Zayani M. (2016) Networked Publics and Digital Contention: The Politics of Everyday Life in Tunisia, Oxford: Oxford University Press.

\section{COVID-19 в виртуальных сетевых коммуникациях: эффекты «спирали молчания»}

\section{Артур Атанесян}

Доктор политических наук, профессор, заведующий кафедрой прикладной социологии, Ереванский государственный университет (Армения)

Адрес: Ереван, ул. Алека Манукяна 1, оо25, Армения

E-mail: atanesyan@ysu.am

\section{Анаит Акопян}

Аспирантка, кафедра прикладной социологии, Ереванский государственный университет (Армения) Адрес: Ереван, ул. Алека Манукяна 1, о025, Армения

E-mail: anahit1989@gmail.com

\section{Брэдли Рейнольдс}

Докторант, Университет Хельсинки (Финляндия)

Адрес: P.O. Box 4 (Yliopistonkatu 3), o0014 University of Helsinki, Finland

E-mail: bradley.reynolds@helsinki.fi

Основной вопрос исследования: характерна ли логика теории «спирали молчания» (Э. НоэльНойман), описывающая механизмы воздействия традиционных СМИ на общественное мнение, для динамики обсуждений вопросов в виртуальных социальных сетях. В качестве актуальной темы взята пандемия COVID-19. На первом этапе полевого исследования был осуществлен вторичный анализ результатов четырех массовых социологических опросов, проведенных в Армении в период активной стадии пандемии. На втором этапе, в период 
с 1 июля - по 30 августа 2020 года (самые высокие показатели пандемии в Армении) был проведен анкетный опрос на базе Google Forms среди армянских пользователей социальной сети Facebook как наиболее распространенной в стране. Было выявлено, что, будучи осведомлено об официальных ограничениях общественного поведения в условиях пандемии и зная о соответствующих санкциях за их нарушение, большинство опрошенных предпочитает публично с ними соглашаться, однако фактически им не следует, что создает диссонанс между массовой коммуникацией о COVID-19 и социальным (фактически антисоциальным) поведением, затрудняя борьбу с пандемией. Установлена зависимость между отношением пользователей к публикуемому в социальной сети мнению «друзей» и посторонних, и предпочтением открытого выражения своего отношения, в частности, комментированием чужих постов. Самопрезентация как стратегия коммуникативного поведения пользователей в Facebook, выражается в нежелании рисковать своей репутацией и подвергать свое мнение открытой и массовой критике: воспринимая сложившуюся коммуникативную ситуацию как опасную, пользователи социальных сетей предпочитают либо соглашаться с мнением других, либо вообще не выражать свое мнение. Результаты данного исследования могут быть полезными как для дальнейшего развития теории социальных коммуникаций и ее применения в новых условиях, так и для изучения и понимания коммуникативного поведение в виртуальных социальных сетях.

Ключевые слова: теория «спирали молчания», социальные сети, массовые коммуникации, поведение, пандемия COVID-19, коллективистские общества, Армения, Facebook 